DOI https://doi.org/10.18551/rjoas.2018-09.41

\title{
DEVELOPMENT STRATEGY OF CIKRA 1 VOCATIONAL HIGH SCHOOL IN EAST JAKARTA
}

\author{
Purwaningrum Chanissa*, Hubeis Musa, Sukandar Dadang \\ School of Business, Bogor Agricultural University, Indonesia \\ *E-mail: chanissap@gmail.com
}

\begin{abstract}
Education is very essential for the progress of a nation. School is a place for young people to get education, so they can compete in the world of work. Educational institutions, especially formal education, compete to be the best in terms of the quantity and quality of graduates, students, and educators. Schools receive excellent accreditation or "A" grades from measuring the quality of schools in providing public sector services and receiving excellent ratings from eight standards of accreditation instruments. Currently, Cikra 1 Vocational High School receives "B" accreditation score. Therefore, in this research, Cikra 1 Vocational High School must prepare appropriate strategies to improve school accreditation in the coming years. This research was conducted by using qualitative method through direct interviews with respondents with the use of questionnaires. The results of the questionnaires and interviews then became the expert considerations in analyzing internal and external factors which were then analyzed by using External Factor Evaluation (EFE), Internal Factor Evaluation (IFE) and IE (Internal/External) matrices to find out the condition of the school. Moreover, SWOT analysis (Strengths-Weaknesses-Opportunities-Threats) was applied to determine the choice of strategy and was continued with QSPM (Quantitative Strategic Planning Matrix).
\end{abstract}

\section{KEY WORDS}

Accreditation, development strategy, SWOT, vocational high school.

According to the data from Central Bureau of Statistics, education in Indonesia in 2014 was mostly dominated by graduates of High School as much as $36.99 \%$. This has become a challenge for educational institutions to become schools that have the best quality and to produce graduates who are able to compete in the world of work and continue their education at higher education. A school has a very good accreditation or "A" score, because it is measured by the quality of the school in providing public sector services and getting a very good assessment of the eight standard accreditation instruments. Cikra 1 Vocational High School is a private school established by the Cikra 1 foundation to provide the best possible educational services which have been accredited with "B" score. Cikra 1 Vocational High School has one department, i.e. accounting that consists of business and management program.

Initially, Cikra 1 Vocational High School only had seven students in one class. However, a few years later, after 1994, there was an increase. In the academic year of 2017/2018, the number of students reached 97 students consisting of three classes, i.e. X, $\mathrm{XI}$, and XII classes. Cikra 1 Vocational High School has 15 teachers and two employees which includes one administrative staff and one IT (Information Technology) staff who also serve as cleaning service staff. The Human Resources which includes educators and employees are considered not appropriate because the number of educators is still very lacking. With so many subjects in the accounting department, having 15 teachers does not make it works conducive.

In addition, some teachers teach subjects that are not in accordance with their fields so that the learning process that should have been in accordance with the curriculum has not been implemented. The learning media made by the teachers have not been implemented properly. School facilities and infrastructure are the determining factors for the success of teaching and learning activities to run well. The facilities and infrastructure of Cikra 1 
Vocational High School are inadequate which includes classes, laboratories, teaching media, computers, yards, and business centers. Based on these problems, a research will be conducted at Cikra 1 Vocational High School entitled "Development Strategy of Cikra 1 Vocational High School in East Jakarta".

The objectives of the research were: (1) evaluating school quality standards according to accreditation standards for vocational high school, (2) identifying internal and external factors affecting the development of Cikra 1 Vocational High School in East Jakarta, and (3) formulating selected alternative strategies and priorities which development can be applied to improve the performance in Cikra 1 Vocational High School in East Jakarta.

\section{METHODS OF RESEARCH}

The research was conducted at Cikra 1 Vocational High School located at Cipinang Kebembem No. 32, Pulogadung of East Jakarta. Research period was June 2018.

The data processing and data analysis of this research was carried out by applying stages from several matrices that contained David's concept (2015):

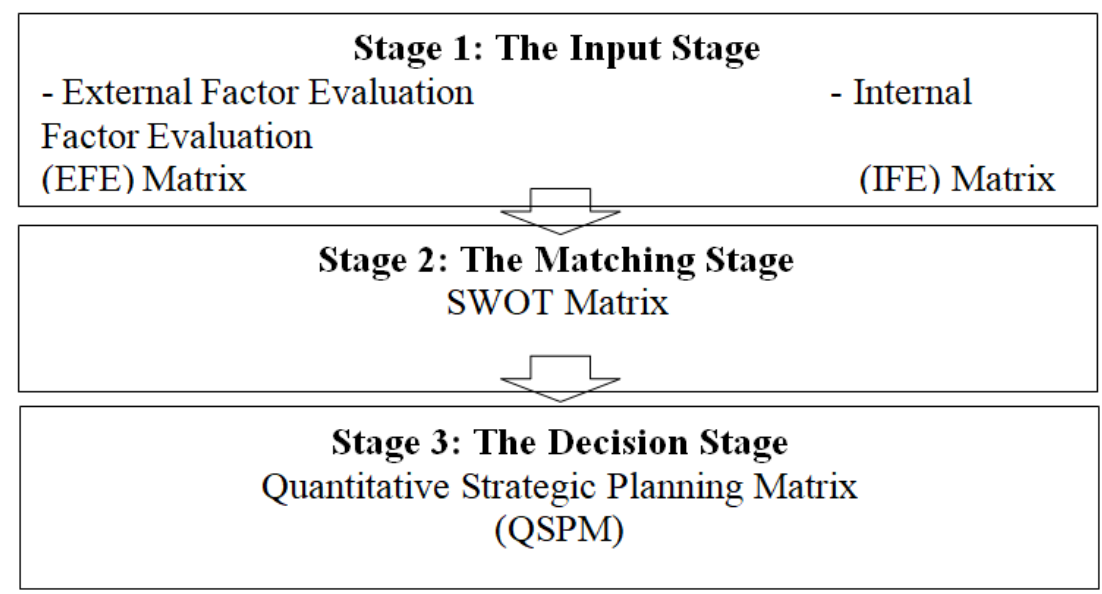

Figure 1 - Stages in Applying Several Matrix Analyses (Source: David, 2015)

The data type included primary and secondary data. Primary data were obtained through direct interviews with respondents using questionnaire and direct field observation. Secondary data were obtained through internal data from Cikra 1 Vocational High School of East Jakarta and literature studies from various research articles related to school development. The sampling technique of this study applied a purposive sampling or judgment sampling technique which was then used as the samples of the research with the consideration that the selected respondents had the ability to develop school quality, school accreditation, and ability to formulate development policies and strategies for Cikra 1 Vocational High School of East Jakarta. The respondents selected to fill out the questionnaire were the principal of SMK Cikra 1 East Jakarta, vice principal of the curriculum section, vice principal of the student-affairs section, senior teacher and school supervisor for East Jakarta Area.

\section{RESULTS AND DISCUSSION}

Development History of Cikra 1 Vocational High School of East Jakarta. The graduates of Cikra 1 Vocational High School are able to be independent and competitive in filling labor needs.

Missions:

- Increasing human resources who are cautious, faithful, virtuous, and are obedient in worship so that they are useful for the development sector; 
- Equipping students with knowledge, skills, and professional attitudes by implementing effective teaching and learning activities in schools and industry and develop their potential in a sustainable manner;

- Improve teacher and employee professionals through training, seminars, internships, and formal education.

Cikra 1 Vocational High School of Jakarta is a private-owned vocational high school established in 1990 in which its status was recognized with a statistical number 342016402052. The initial location of Cikra 1 Vocational High School was at Jalan Cikini Raya, Central Jakarta but now it moved on Jalan Cipinang Kebembem No. 32 East Jakarta. Initially, Cikra 1 Vocational High School had an automotive and accounting department. However, due to the decline in the number of students each year in 1995, it currently only had one accounting department with business and management programs. Currently the number of students is growing rapidly compared to 1995. Currently, it has 114 students with 15 teachers, 2 extracurricular teachers, and 2 employees.

Table 1 - Number of Students per Academic Year

\begin{tabular}{llll}
\hline Academic Years & Number of Students & New Students & Graduates \\
\hline $2013 / 2014$ & 127 & 50 & 45 \\
$2014 / 2015$ & 122 & 44 & 20 \\
$2015 / 2016$ & 121 & 27 & 50 \\
$2016 / 2017$ & 94 & 38 & 35 \\
$2017 / 2018$ & 97 & 41 & 21 \\
\hline
\end{tabular}

The number of teachers in Cikra 1 Vocational High School was 15 people consisting of eight teachers who taught national content subjects and six teachers who taught specialization subjects and one teacher who served counseling guidance. The school staffs of Cikra 1 Vocational School consist of one administrative person and one IT staff. Vocational subjects in accounting program consisted of 8 national content subjects and 14 specialization subjects in which the number of time allocation per week was 48 hours. The following is data on the development of the number of teachers and school staffs.

Table 2 - Data on the Development of the Number of Teachers and School Staffs

\begin{tabular}{lll}
\hline Academic Years & Teachers & School Staffs \\
\hline $2013 / 2014$ & 14 & 2 \\
$2014 / 2015$ & 14 & 2 \\
$2015 / 2016$ & 15 & 2 \\
$2016 / 2017$ & 15 & 2 \\
$2017 / 2018$ & 15 & 2 \\
\hline
\end{tabular}

The Analysis of Strategic Factors. According to the National Accreditation Board for Schools / Madrasahs, there are eight accreditation standards in Accreditation Instruments for Vocational High School which are the benchmark of school accreditation. The eight standards are:

- Standards of Content, which contains the curriculum;

- Standards of Process, including lesson plan, subjects and learning processes;

- Standards of Graduates Competency, including the assessment of students and selfdevelopment activities;

- Standards of Teachers and Staffs, including qualifications of teachers and staffs;

- Standards of Facilities and Infrastructure, including assessments related to the provision of school facilities and infrastructure;

- Standards of Management, including infrastructure management, learning activities, student activities, and supervision;

- Standards of Assessment, covering the principle of assessing student learning outcomes.

Based on the results of the accreditation, the education quality standards that need to be improved must be evaluated. From these data, it was found that the lowest standard 
score was standards of teacher and staffs 76.23 , standards of process 76.74 , and standards of facilities and infrastructure 77.22.

Table 3 - Accreditation Results of Cikra 1 Vocational High School of East Jakarta

\begin{tabular}{llllllll}
\hline No & Components & WEIGHT & STM & STP & NK & NSR & Appropriateness \\
\hline 1 & Standards of Content & 12 & 216 & 181 & 10.06 & 83.8 & Appropriate \\
2 & Standards of Process & 15 & 172 & 132 & 11.51 & 76.74 & Appropriate \\
3 & Standards of Graduates Competency & 13 & 384 & 301 & 10.19 & 78.39 & Appropriate \\
4 & Standards of Teachers and Staffs & 15 & 324 & 247 & 11.44 & 76.23 & Appropriate \\
5 & Standards of Facilities and Infrastructure & 13 & 316 & 244 & 10.04 & 77.22 & Appropriate \\
6 & Standards of Management & 10 & 320 & 272 & 8.5 & 85 & Appropriate \\
7 & Standards on Financing & 11 & 332 & 296 & 9.81 & 89.16 & Appropriate \\
8 & Standards of Assessment & 11 & 260 & 250 & 10.58 & 95.15 & Appropriate \\
\hline Final Score of Accreditation & & & & 82.13 & & \\
Accreditation Rate & & & & & & \\
\hline
\end{tabular}

Based on the data of the accreditation standard, the strategic factors in the development of Cikra 1 Vocational High School Jakarta were based on in-depth interviews with internal parties (from Cikra 1 Vocational High School Jakarta and external parties (school supervisors). Strategic factor analysis for the development of Cikra 1 Vocational High School Jakarta is as follows:

Strengths:

Utilization of information and communication technology. Cikra 1 Vocational High School has utilized technology in computer-based learning methods and examinations, i.e. by using software in accounting subjects, as well as using other devices such as in-focus and computers. In addition, some of the tasks given by the teacher are completed using e-mail and internet. In taking a national quality control test as well as a National Examination, Cikra 1 Vocational High School has also used online computer-based tests independently.

The curriculum has been implemented in accordance with the applicable standards. Education standards in Indonesia cannot be separated from the policies of the Government, especially the Ministry of Education and Culture. Cikra 1 Vocational High School has implemented the curriculum that applies in the 2017/2018 academic year; Grade X and Grade XI apply the 2013 Curriculum while Grade XII continues the Education Unit Level Curriculum. Based on government regulations, related to the curriculum, Cikra 1 Vocational High School applies learning media, student assignments, and assessment of student learning outcomes that are adapted to the curriculum structure.

Appropriateness of the implementation of activities with the work plans. Cikra 1 Vocational High School has implemented a work plan made by the vice principal. The work plan includes new student admission, introduction to school environment for new students, work meetings, determination of teaching hours, August 17 celebration, celebration of religious activities, midterm exams, final exams, student competency exams, computer standard national exams, school examinations in national standards, collection of student learning outcomes, distribution of report cards, student leadership basic training activities, year-end activities (study tours), industrial work practices in the business world/ industrial world, and industrial visit activities.

Financing school operational costs properly. Cikra 1 Vocational High School has made good financing and management arrangements for various needs it requires. It includes the budget for conducting examinations, school operational costs, activities for 3 years; as well as making financial budgets, reporting and accountability.

Weaknesses:

Limited student self-development activities. Cikra 1 Vocational High School has not been optimal in organizing student self-development activities which in which it never provides choral, basketball and accounting training activities. Although it is currently heading towards the provision of activities, i.e. applying the extracurricular program of karate, Cikra 1 Vocational High School also does not have a Paskibraka (National Flag Hoisting Troop) team. If there is an event that requires the Paskibraka team to appear in a complete 
formation, training will be carried out seasonally. Currently, the extracurricular includes only scouts and karate.

The average score of the National Examination in the last year is relatively low. National Examination is one of the final assessments that determine graduation in addition to the National Standard School Examination and School Examination. However, from the data of the last 3 years, there is a decrease in the national exam scores as well as the average score of the national examination. The following is the score data of Cikra 1 Vocational High School for the last three years starting from the 2015/2016 up to the $2017 / 2018$ academic year.

The figure below shows that the average score of the national exam of Cikra 1 Vocational High School in the 2017/2018 academic year has decreased from the previous two years with the highest average acquisition score of 6.60 and the lowest average of 4.99, from 2016 / 2017 with the highest average score of 8.50 and the lowest average score of 5.70 which is almost the same as the average score of the National Examination for the 2015/2016 academic year with the highest acquisition score of 8.53 and the lowest of 5.70. Regarding to the assessment of learning outcomes according to Minister of Education and Culture Regulation No. 4 of 2018, assessment by the education unit is carried out through the School Examination and the National Standard School Examination. In addition, the final assessment from the government is carried out through the National Examination (UN).

Minister of Education and Culture Regulation No. 4 of 2018 Article 17 explains that the results of the National Examination are used as a basis for: a) mapping the quality of programs and/or Education Units, b) selection considerations to enter the next Education Level, and c) guidance and assistance to the Education Unit in an effort to improve quality education. Therefore, although it is not the only benchmark for graduating from vocational high school, it is still considered important because the National Examination score is part of the overall process of graduation score.

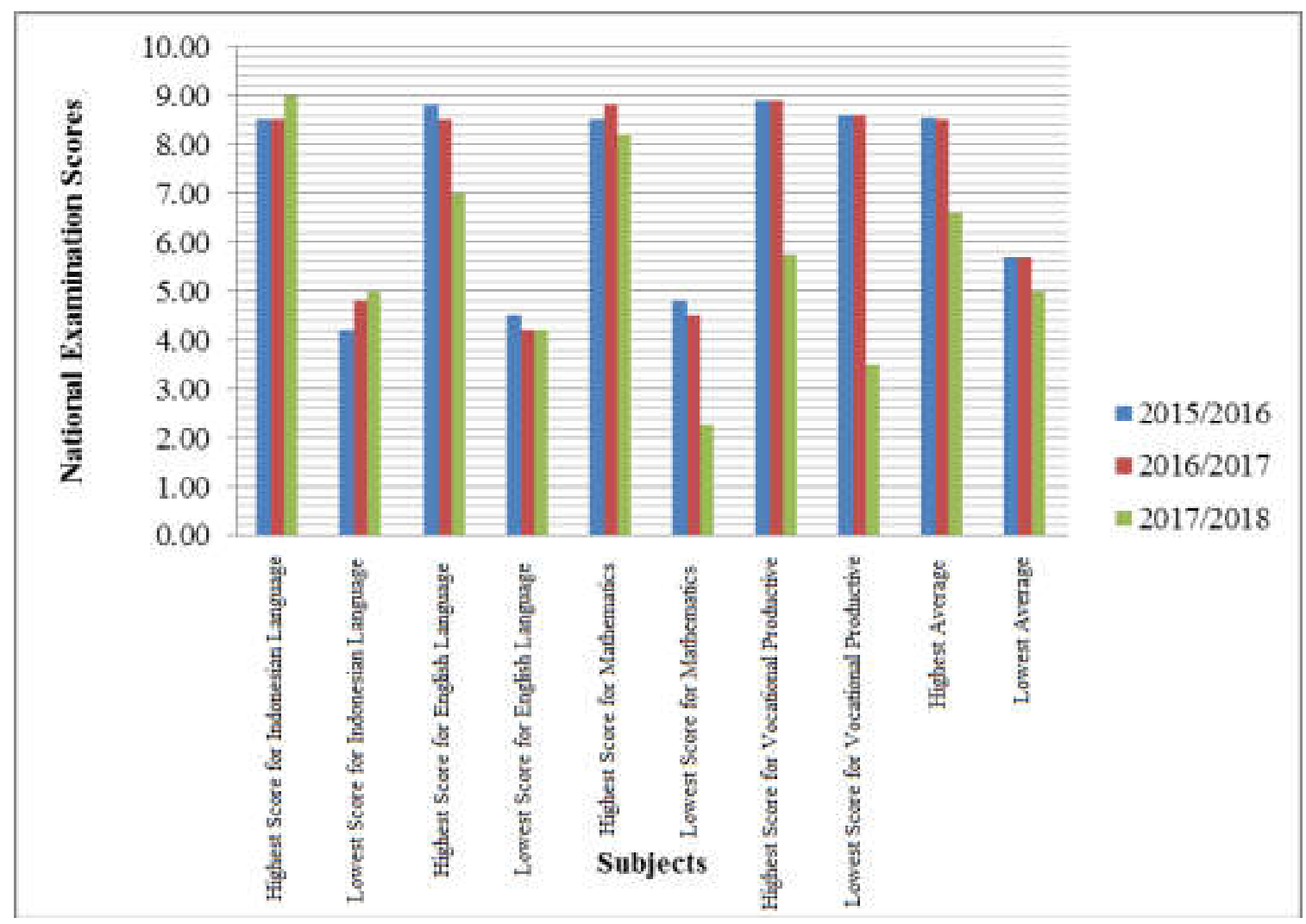

Figure 2 - Scores of National Examination of Cikra 1 Vocational High School Jakarta in the 2015/2016 Academic Year up to 2017/2018 Academic Year (Source: Internal Data of Cikra 1 Vocational High School Jakarta) 
The learning process is not yet in accordance with the Lesson Plan. Cikra 1 Vocational High School Jakarta applies Education Unit Level Curriculum for XII Grade and 2013 Curriculum for X and XI Grades. There are several obstacles during the process of teaching and learning activities including the 2013 curriculum-as the reference-that requires students to be able to think high up to the creating level. Meanwhile, in Cikra 1 Vocational High School, it is still difficult to understand and do by students even it is only to analyzing level. Teachers need to develop learning media together so students can develop themselves in accordance with the applicable curriculum. The learning process is not yet in accordance with the learning media made by subject teachers. When the school principal or vice principal supervises the teacher of each subject, it is found that some they are teaching not in accordance with the basic competencies that it should be. In addition, the learning methods are still the same as the previous curriculum, i.e. lectures.

Lack of competency training activities for teachers. Cikra 1 Vocational High School has never held competency training for teachers either in teaching competencies, online grades processing, 2013 curriculum or accounting training. Then, it is rarely for Cikra 1 Vocational High School to send its teachers to some training in accordance with their fields at the East Jakarta education and training center. It is required to add some insights and competences of the teachers in teaching and add certificates that must be possessed by a productive teacher.

Facilities and infrastructure supporting educational activities are still limited. Facilities and infrastructure for Cikra 1 Vocational High School Jakarta are still limited. Among them are buildings that are not private property. Cikra 1 Vocational High School rented buildings annually to Srikandi Junior High School foundation. In addition, the condition of the room is not appropriate, in which the classrooms are rather dark and humid because when the rainy season comes the class leaks and floods. The computers provided in the laboratory are only 15 units and 1 operator unit without a backup server.

The printer provided is only 1 unit for students and 1 unit for operator in a computer laboratory and 1 pair unit of computer and printer for the IT staff as a school operator within the teacher's room. Cikra 1 Vocational High School does not have an accounting laboratory where every business management vocational high school commonly has a vocational laboratory and also does not have a business unit such as a mini market. Cikra 1 Vocational High School does not have a student room or Student Health Room. The school does not have a business center, a place where students can carry out entrepreneurial activities in accordance with their skill competencies. The school does not have a good yard; the contour of the floor is not neat because there are holes that are not repaired in which the students might get injury during the exercise.

\section{Opportunities:}

Government policy regarding 12-year compulsory education. In the era of globalization, humans are now required to improve their ability to enhance the quality of human resources. Therefore, the government creates an education program of "Smart Indonesia". The implementation of learning programs cannot be separated from government regulations that require the program to realize quality human resources. The legal basis of the 12-year compulsory education program is: (1) Law No. 20 of 2003, (2) Decree of the People's Consultative Assembly No. 9 of 2007 concerning the education fund budget, (3) Law No. 32 of 2004 concerning Regional Autonomy, (4) Government Regulation Number 32 of 2007 concerning the division of authority between the Central Government and the Autonomous Region, (5) Government Regulation No. 19 of 2005 concerning National Education Standards, (6) Government Regulation No. 1 of 2004 concerning the Strategic Plan for Provincial Development, (7) Regional Regulation No. 1 of 2007 concerning the Provincial Regional Expenditure Budget. Based on those legal bases, the government made the Minister of Education and Culture Regulation of the Republic of Indonesia No. 19 of 2016 concerning the "Smart Indonesia" Program. The Smart Indonesia Program is one of the government's efforts to support the implementation of universal secondary education or a 12year compulsory education program. 
The 12-year compulsory education program creates an opportunity for Cikra 1 Vocational High School to get prospective students who will study until they graduate in order to achieve government programs i.e. realizing quality human resources.

Utilizing the Smart Jakarta Card and other higher school tuition fees. The regional government of Jakarta establishes the Smart Jakarta Card Plus in 2018. The Smart Jakarta Card Plus funds can be used in cash and non-cash. Vocational High School earns IDR $450,000 /$ month which can be spent IDR 235,000 / month. In addition, other facilities provided by the Smart Jakarta Card are boarding free Trans Jakarta buses, shopping for six types of food at low prices, and free entry to Ancol.

Diponegoro 1 Vocational High School applies tuition fees with a total amount of IDR $10,995,000$ and can be paid in full or paid in installments. Pelita Tiga Vocational High School applies a medium tuition fee of IDR 4,425,000. It is different to Tunas Markatin Vocational High School which has a tuition fee of IDR 2,000,000 for the entrance fees and IDR 260,000 for the school fee. The tuition fees offered by several schools around Cikra 1 Vocational High School are around IDR 2,000,000 to IDR 10,000,000. With the existence of KJP and other higher school tuition fees, it became an opportunity for Cikra 1 Vocational High School. Prospective students who do not have enough money can attend Cikra 1 Vocational High School. Cikra 1 Vocational High School offers accounting program at relatively affordable prices for middle to lower class people. Cikra 1 Vocational High School also proposes KJP funds for students who want to be helped in school payments. Currently Cikra 1 Vocational High School applies monthly school payments of IDR 175,000 and computer fees and Student Organization of IDR 150,000 . If the students have the Smart Jakarta Card, monthly school fees can be auto debit from school. Therefore, the students are only required to pay IDR $150,000 /$ month. If the limit in the the Smart Jakarta Card account is still available then it can be debited directly.

Threats:

The existence of other schools with better facilities. Diponegoro 1 Vocational High School Rawamangun offers facilities and infrastructure that are fairly good and attractive; among them are the principal's and vice principal's office, teacher's room, administrative services, library, production unit room, shared room, toilet, warehouse, student dormitory, Counseling Guidance room, Student Organization room, cooperative room, Student Health Unit room, guard school room, futsal courts, basketball courts, air-conditioned classrooms, practice room/ workshop, computer and network practice rooms, multimedia rooms, office administration rooms, accounting rooms, marketing spaces, and very large mosques for places of worship. Diponegoro 1 Vocational High School library has been well managed compared to before. It has many books such as Indonesian Language, Mathematics, English Language, office administration, multimedia, and computer and network engineering

Pelita Tiga Vocational High School is located not far from Cikra 1 Vocational High School which is located on Jl. Rawajaya I, No. 43 Pisangan Timur which has a three-floor building, prayer room, production units, libraries, accounting laboratories, office administration laboratories, computer laboratories, language laboratories, full air-conditioned classrooms, free Wi-Fi, parking areas and sports yards. Tunas Markatin Vocational High School which is located in East Jakarta Klender has several self-owned building facilities, which consist of libraries, air-conditioned classrooms, office accounting and administration laboratories, and production units. School facilities and infrastructure facilities are supporting factors for the success of teaching and learning process. If other schools have complete and better facilities, it encourages prospective students to switch to schools with the best facilities.

Other larger school compensation. The school applies several provisions to provide compensation to teachers and employees. Diponegoro Vocational High School provides a teaching fee of IDR 40,000 per hour and an estimated transport fee of IDR 70,000. Pelita Tiga Vocational High School which is located not far from Cikra 1 Vocational High School provides compensation by calculating the teaching hours by providing compensation of IDR 25,000 and an estimated transport fee of IDR 20,000. 
That is different from Tunas Markatin Vocational High School which is located in the Klender area of East Jakarta, which uses a life clock calculation. It means if a teacher has 20 teaching hours $\times 4$ (number of weeks in one month) x IDR 30,000 (honorarium/ hour). In addition for arrivals transport is IDR 20,000 (Morning) and IDR 20,000 (Afternoon). If a teacher teaches from morning to the evening, he/she gets IDR 40,000.

Compensation is very important for teachers and employees. The amount of compensation for each school varies depending on the agreement of the principal and other management. Cikra 1 Vocational High School applies teacher fees per hour of IDR 15,000. So if a teacher has 10 hours of teaching, his/ her honorarium is IDR 150,000. In addition to the teaching hour honorarium there is also a transport fee paid per arrival of IDR 30,000 in accordance with the teacher's teaching schedule. So, if a teacher teaches 3 days in one week then he/she gets IDR 90,000. This can be multiplied by the number of days of arrival in one month.

Some teachers might compare compensation with other schools and choose to resign from Cikra 1 Vocational High School. Some have moved to other schools as well as to tutoring places to get better wages. The transfer of several teachers to other teaching places will have an impact on the quality of the teachers who are not conducive during the day. In addition, it has an impact on the teacher's performance which has decreased due to having to divide the time between one school and another school, especially in making exam questions, meeting and recreation.

Other school competency skills that are more varied. Diponegoro Vocational High School offers expertise in accounting, marketing, office administration and multimedia skills. Meanwhile, Pelita Tiga Vocational High School offers expertise in accounting and office administration skills. It is similar to the competencies offered by Vocational High School in other business and management fields such as Tunas Markatin Vocational High School.

Cikra 1 Vocational High School Jakarta offers one skill competence, namely accounting with the field of business management expertise. Some schools around Cikra 1 Vocational High School Jakarta both state and private Vocational High Schools have at least three skills competencies, namely accounting, office administration, and marketing for business management expertise. Several other schools also extend to computer engineering with network computer engineering expertise. With the limited education program offered by Cikra 1 Vocational High School, it makes some prospective students choose another school because Cikra 1 Vocational High School is not in accordance with the interests and talents of prospective students.

IFE Matrix:

Internal environmental analysis was conducted through identification of internal factors of Cikra 1 Vocational High School to analyze the strengths and weaknesses of the school. After being identified, weighting and rating of each variable was carried out. Based on the results of weighting and rating using the IFE matrix, it was known that the total score of the IFE matrix is 2.4028 .

An important factor from the biggest weight is the weight of Suitability of Implementation of Activities with a work plan of 0.14444 and score of 0.4333 and the supporting facilities and infrastructure of educational activities are still limited with a weight of 0.1236 and a score of 0.1236 .

The highest rating strength factor (4) that must be increased by Cikra 1 Vocational High School is the use of information and communication technology (ICT) and curriculum implemented in accordance with applicable standards. The weakness factor that must also be considered by Cikra 1 Vocational High School East Jakarta was the average score of the National Examination in the last year which was relatively low, the learning process that is not yet in accordance with the Lesson Plan and limited supporting facilities and infrastructure of the educational activities, Purwandari (2015). In the internal factor evaluation matrix, the weight score ranged between 1.0 as the lowest point and 4.0 as the highest point, with an average score of 2.5. The total internal factor weight score is 2.4028 and is categorized in the medium rate and the value has sufficient weaknesses and distinctive strengths and also has sufficient prerequisites for further development. 


\section{EFE Matrix:}

EFE matrix analysis is the result of the identification of external factors in the form of opportunities and threats affecting Cikra 1 Vocational High School. Based on the EFE matrix (Table 14), the total value of the external factor is 2.3600 . An important factor that can be seen from the biggest weight is the utilization of Jakarta Smart Card and other school fees that are more expensive with a weight of 0.23500 and a score of 0.9400 , and other school compensation that is greater with a weight of 0.20500 and score of 0.4100 . The highest rating opportunity factor (4) that can be utilized by Cikra 1 Vocational High School of East Jakarta is the Utilization of Smart Jakarta Card and other higher school tuition fees. Cikra 1 Vocational High School must face external threats, namely the existence of other schools with better facilities and various other school skills competencies.

Table 4 - Internal Factor Evaluation (IFE) Matrix

\begin{tabular}{|c|c|c|c|c|}
\hline & Internal Critical Factors & $\begin{array}{l}\text { Weight } \\
\text { (a) }\end{array}$ & $\begin{array}{l}\text { Rank } \\
\text { (b) }\end{array}$ & $\begin{array}{l}\text { Scores } \\
(a \times b)\end{array}$ \\
\hline & \multicolumn{4}{|l|}{ Strengths } \\
\hline 1 & Use of ICT & 0.12361 & 4 & 0.4944 \\
\hline 2 & The curriculum has been implemented according to applicable standards & 0.1125 & 4 & 0.45 \\
\hline 3 & Suitability of the implementation of activities with the work plans & 0.14444 & 3 & 0.4333 \\
\hline \multirow[t]{3}{*}{4} & Financing school operational cost appropriately & 0.10417 & 3 & 0.3125 \\
\hline & Total of Strengths & 0.48472 & & 1.6903 \\
\hline & \multicolumn{4}{|l|}{ Weaknesses } \\
\hline 1 & Limited student self-development activities & 0.1083 & 2 & 0.2167 \\
\hline 2 & The average score of the National Examination in the last year is relatively low & 0.0986 & 1 & 0.0986 \\
\hline 3 & The learning process is not yet in accordance with the lesson plan & 0.0958 & 1 & 0.0958 \\
\hline 4 & Lack of competency training activities for teachers & 0.0889 & 2 & 0.1778 \\
\hline \multirow[t]{3}{*}{5} & Limited facilities and infrastructure supporting educational activities & 0.1236 & 1 & 0.1236 \\
\hline & Total of Weaknesses & 0.5153 & & 0.7125 \\
\hline & Total Scores of Internal Factors & 1 & & 2.4028 \\
\hline
\end{tabular}

Table 5 - External Factor Evaluation (EFE) Matrix

\begin{tabular}{|c|c|c|c|c|}
\hline & Internal Critical Factors & Weight & Rank & Scores \\
\hline & \multicolumn{4}{|l|}{ Opportunities } \\
\hline 1 & Government policy regarding 12-year compulsory education & 0.225 & 3 & 0.675 \\
\hline \multirow[t]{3}{*}{2} & Utilization of Smart Jakarta Card and other school fees which are more expensive & 0.235 & 4 & 0.94 \\
\hline & Total of Opportunities & 0.46 & & 1.615 \\
\hline & \multicolumn{4}{|l|}{ Threats } \\
\hline 1 & The existence of other schools with better facilities & 0.195 & 1 & 0.195 \\
\hline 2 & Other higher school compensation & 0.205 & 2 & 0.41 \\
\hline 3 & Other school competency skills that are varied & 0.14 & 1 & 0.14 \\
\hline & Total of Threats & 0.54 & & 0.745 \\
\hline & Total Scores of External Factors & 1 & & 2.36 \\
\hline
\end{tabular}

According to David (2015), the highest score an organization can achieve is 4.0 and the lowest score is 1.0 with an average of 2.5. According to Purwandari (2015), the total weight score of external factors is 2.3600 which are included in the medium category which indicates that the Cikra 1 Vocational High School strategy has sufficient opportunities and at the same time lower threats of possible opportunities and efforts to develop.

Internal External Matrix (IE Matrix). The weighted scores of internal and external factors that have been obtained are then presented in a matrix that can be seen in Figure 3.

After the IFE/ EFE Matrix analysis, the next is determining the current position of Cikra 1 Vocational High School East Jakarta by using IE Matrix. This matrix shows the position of Cikra 1 Vocational High School based on the results of IFE and EFE analysis which means that Cikra 1 Vocational High School is in V cell (stability) average position; it is neither strong nor weak, both internally and externally. According to Purwandari (2015), this stage is in holding and maintaining its position which means that Cikra 1 Vocational High School needs a strategy to be able to keep and maintain its position. The strategy that can be implemented by Cikra 1 Vocational High School is a strategy of market penetration and product 
development. According to Usman and Taren (2013), a combination of internal and external factors of the company is arranged in a systematic and structured manner in order to produce four kinds of strategies. The strategies that are formed are S-O (StrengthOpportunity), S-T (Strength-Threat), W-O (Weakness-Opportunity), and W-T (WeaknessThreat) strategies. Based on the results of the Internal External analysis, the SWOT matrix created is the SO strategy (conducting promotional activities and tuition fees that can be paid in installments), WO strategies (conducting student and teacher self-development activities and optimizing the 2013 curriculum implementation), ST strategy (providing compensation comparable to other schools), and WT strategies (improving school facilities and infrastructure).

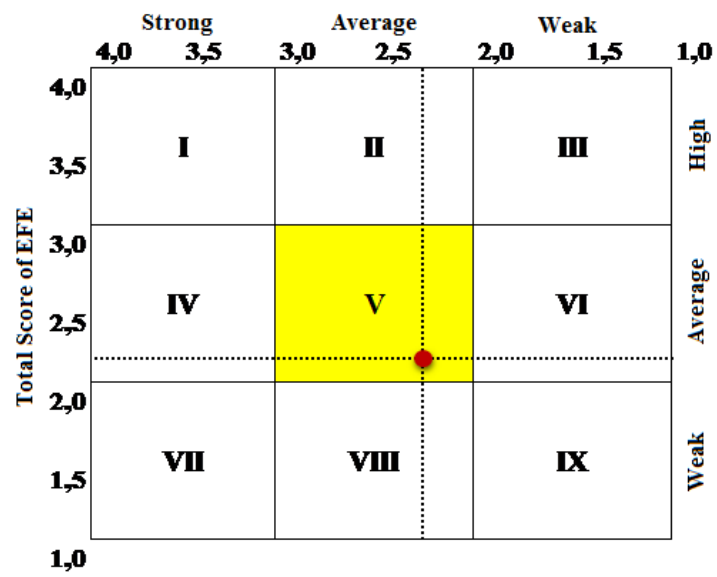

Figure 3 - IE Matrix

Quantitative Strategic Planning Matrix (QSPM). According to Umar (2010), the Quantitative Strategy Planning Matrix (QSPM) is a recommended tool for the strategists to evaluate alternative strategy choices objectively based on internal-external key success factors (KSF) that have been identified before. The final stage in the formulation and strategy selection is the preparation of the QSPM which will produce the priority sequence of the proposed strategy. The QSPM is made by providing an Attractiveness Score (AS) on each key external and internal factor for each proposed strategy. The AS assesses how the level of effect of a key factor on certain alternative strategies (Stefanus and Tarcisius, 2015).

The QSPM analysis produced five alternative strategies in the development of Cikra 1 Vocational High School East Jakarta; namely Strategy I: conduct promotional activities and tuition fees that can be paid in installments, Strategy II: conduct self-development activities of students and teachers, Strategy III: optimize the implementation of the 2013 curriculum, Strategy IV: improve school facilities and infrastructure, Strategy V: provide compensation comparable to another school. Furthermore, from the five strategies, the experts determined the relative attractiveness to indicate the main strategy in which it obtained Priority 1: optimize the implementation of the 2013 curriculum (TAS $=6.35$ ), Priority II: improve school facilities and infrastructure (TAS $=6.20$ ), Priority III: provide compensation that is comparable to other schools (TAS $=5.75$ ), Priority IV: conduct self-development activities for students and teachers (TAS $=5.45$ ), Priority $\mathrm{V}$ : conduct promotional activities and tuition fees that can be paid in installments (TAS $=4.64)$.

\section{MANAGERIAL IMPLICATIONS}

Managerial implications that can be performed by Cikra 1 Vocational High School to improve school accreditation based on the QSP Matrix analysis are:

First Strategy: optimizing the implementation of the 2013 curriculum. This strategy is used to improve the standards of teachers and school staffs and standards of process. The teacher must carry out teaching and learning activities in accordance with the learning media 
made based on the curriculum development of each subject. It is also expected that the teachers can implement the 2013 curriculum appropriately.

The second strategy: improving school facilities and infrastructure. This strategy can be implied by managing school operational funds appropriately every year to improve school facilities and infrastructure and to work with third parties such as educational institutions or social institutions. To meet the financing needs of school facilities and infrastructure, Cikra 1 Vocational High School needs to add computers and props to each subject based on the needs.

Third strategy: providing compensation comparable to other schools. Compensation is the right of teachers and staffs who have completed their work properly. For this reason, it is necessary to increase the allowances of the homeroom teachers, counseling teacher, vice principal and hourly teacher salaries which are comparable to other schools in East Jakarta, as well as holiday allowances for teachers and staffs as applied to other schools, and the provision of Insurance Facilities of Social Security Agency.

The fourth strategy: conducting student and teacher self-development activities. This strategy can be applied by carrying out an activity that aims to train students, both in skills, attitudes, mental, and critical ways of thinking according to the demands of the 2013 curriculum and also for teachers about how to make learning methods or the making of questions that lead to high-order thinking skill. Such activities can be carried out in collaboration with State Vocational High School 48 East Jakarta or other parties such as educational institutions, motivational institutions, and education and training centers in East Jakarta. In addition to self-development in the academic field, several other things that need to be added are student extracurricular activities.

The fifth strategy: conducting promotional activities and tuition fees that can be paid in installments. Cikra 1 Vocational High School can apply financing that can be paid in installments and is relatively affordable for the middle to lower community class.

\section{CONCLUSION}

Accreditation data of Cikra 1 Vocational High School require improvement, especially at the lowest standard value consisting of standards of teacher and staffs of 76.23 , standards of process 76.74 , and standards of facilities and infrastructure of 77.22.

The results of internal factor analysis on the strength factor with the highest rating are the use of ICTs and curricula which have been implemented according to the applicable standards. The weakness factor that must also be considered by Cikra 1 Vocational High School East Jakarta is the average score of the National Examination in the last year which is relatively low. The learning process is not yet in accordance with the lesson plan and the supporting facilities and infrastructure of education activities are still limited. The results of the analysis of external factors on the highest rating opportunity factor (4) that can be utilized by Cikra 1 Vocational High School East Jakarta is the utilization of the Smart Jakarta Card and other higher school tuition fees. Cikra 1 Vocational High School must face external threats in the form of other schools with facilities better and varied school skills competencies. Based on the analysis of internal and external factors combined in IE Matrix, it can be stated that Cikra 1 Vocational High School East Jakarta is in cell V, namely Market Penetration and Product Development strategies.

The main strategy that must be carried out by Cikra 1 Vocational High School East Jakarta is to optimize the implementation of the 2013 curriculum; focus on developing the 2013 curriculum according to students' backgrounds, subjects, learning methods and implementing the curriculum according to the learning media that have been created by the teacher. Another alternative strategy is to improve school facilities and infrastructure, provide compensation comparable to other schools, conduct student and teacher self-development activities, carry out promotional activities and provide tuition fees that can be paid in installments. 


\section{REFERENCES}

1. [BAN-S/M] Badan Akreditasi Nasional Sekolah/Madrasah. 2017. Perangkat akreditasi SMK. Jakarta Timur (ID): BAN S/M

2. [BPS] Badan Pusat Statistik Provinsi DKI Jakarta Timur. 2016. Persentase penduduk yang usia 10 tahun ke atas menurut pendidikan tertinggi yang ditamatkan, 2010-2014 [internet]. [diunduh 2016 Desember 17].

3. David FR. 2015. Manajemen Strategik. Ed ke-12. Sunardi D, penerjeman. Wuriarti P, editor. Jakarta Timur (ID): Salemba Empat. Terjemahan dari Strategic Management.

4. Purwandari S. 2015. Analisis Quantitative Strategic Planning Matrix (QSPM) sebagai landasan menentukan strategi pemasaran pada SMK Citra Medika Sukoharjo. Jurnal Sainstech Politeknik Indonusa Surakarta. 1(3): 1-9

5. Stefanus $P$, Tarcisius T.S . 2015. Formulasi dan pemilihan strategi dengan menggunakan teknik Quantitative Strategic Planning Matrix (QSPM) (Studi kasus pada penyelenggara jasa internet nethost di Dayeuh Kolot, Kabupaten Bandung). Jurnal e-Proceeding of Management 3(2): 2723- 2731

6. Umar H. 2010. Desain Penelitian Strategik: Cara Mudah Meneliti Masalah-Masalah Manajemen Strategik Untuk Skripsi, Tesis Dan Praktik Bisnis. Jakarta Timur (ID): Rajawali Pers

7. Usman YV, Taren W. 2013. Analisis strategi pemasaran perumahan Bekasi Timur regensi 3. Jurnal Sistem Industri. 7(1):83-98 